The role of CEO's personal incentives in driving corporate social responsibility

\author{
Michele Fabrizi \\ Department of Economics and Management \\ University of Padova \\ michele.fabrizi@unipd.it \\ Christine Mallin \\ Norwich Business School \\ University of East Anglia \\ c.mallin@uea.ac.uk \\ Giovanna Michelon* \\ University of Exeter Business School and \\ University of Padova \\ g.michelon@exeter.ac.uk
}

* Corresponding author

\title{
Acknowledgements
}

The authors are grateful to Claudia Arena, Pietro Bonetti, Antonio Parbonetti and Den Patten for their insightful comments and suggestions. The authors also acknowledge the useful comments received at presentation at the 24th CSEAR International Congress on Social and Environmental Accounting Research (3-5 September 2012, St. Andrews, UK). 


\title{
The role of CEO's personal incentives in driving corporate social responsibility
}

\begin{abstract}
In this study we explore the role of Chief Executive Officers' (CEOs') incentives, split between monetary (based on both bonus compensation and changes in the value of the CEO's portfolio of stocks and options) and non-monetary (career concerns, incoming/departing CEOs, power and entrenchment) in relation to corporate social responsibility (CSR). We base our analysis on a sample of 597 US firms over the period 2005-2009. We find that both monetary and non-monetary incentives have an effect on CSR decisions. Specifically, monetary incentives designed to align the CEO's and shareholders' interests have a negative effect on CSR and non-monetary incentives have a positive effect on CSR. The study has important implications for the design of executive remuneration (compensation) plans, as we show that there are many levers that can affect CEO's decisions with regard to CSR. Our evidence also confirms the prominent role of the CEO in relation to CSR decisions, whilst also recognizing the complexity of factors affecting CSR. Finally, we propose a research design that takes into account endogeneity issues arising when examining compensation variables.
\end{abstract}

Keywords: Chief Executive Officer (CEO), corporate social responsibility (CSR), executive remuneration, monetary incentives, non-monetary incentives. 


\section{The role of CEO's personal incentives in driving corporate social responsibility}

\section{INTRODUCTION}

This study is concerned with the extent to which Chief Executive Officers' (CEOs') incentives affect corporate social responsibility (CSR).

In recent years there has been an increasing interest in CSR, which has led to wide press coverage and a growing number of academic research papers on the topic (Mahoney and Thorne 2005). As pointed out by Porter and Kramer (2006, p. 78), governments, activists and the media have become adept at holding companies to account for the social consequences of their activities and many organizations have started ranking companies on their CSR performance, attracting considerable publicity. As a result, CSR has emerged as a priority for business in every country. Moreover, there is anecdotal and empirical evidence that the CEO is a key decision maker in CSR related decisions. As Waldman et al. (2006, p. 1704) point out, CEOs are charged with the responsibility of formulating corporate strategy and are often deeply involved in promoting the image of their firms through social responsibility. For instance, as reported by Waldman et al. (2006), Anita Roddick, CEO and founder of the Body Shop, developed a new category of cosmetics using ingredients that are based on non-animal testing procedures. Ben Cohen of Ben and Jerry's Ice Cream used a combination of high quality ingredients that supported local businesses and reinvestment of after-tax profits to create and develop a high quality brand. Moreover, since 2008 the CR Magazine (Corporate Responsibility Magazine) awards the most socially responsible CEOs in the US on the extent to which they put themselves at personal and professional risk in order to deliver on corporate responsibility promises, thus recognizing CEOs' leading role in addressing CSR activities. These awards are presented to CEOs across industries who visibly exceed standards in the areas of employee relations, environmental impact, human rights, philanthropy and corporate responsibility practices. From an empirical standpoint, Manner (2010) 
shows that CEOs' personal characteristics are linked to strong or exemplary social performance while Waldman et al. (2006) find that CEO intellectual stimulation is significantly associated with the propensity of the firm to engage in 'strategic' CSR.

All of these considerations strongly suggest that the CEO is particularly relevant in firms' CSR decisions and that CSR plays a pivotal role in many firms. Therefore this paper aims at investigating the effect of the CEO's monetary and non-monetary incentives on CSR. Specifically, we focus on an array of CEO's personal incentives that we expect to influence CSR decisions: equity incentives, annual bonuses, career concerns, incoming/departing CEOs, and power and entrenchment.

We base our archival analysis on a sample of 2,520 firm-year observations from 597 unique US firms over the period 2005-2009. We use CSR data from the Ethical Investment Research Services (EIRIS), a UK based independent research company specializing in the assessment of CSR against a consistent and objective set of criteria, principally for investors' use. EIRIS has 20 years dedicated social research experience, with the largest and most complete multidimensional social performance coverage of world-wide firms and has been used in previous CSR related studies (Brammer et al., 2006; Cox et al., 2004; Moore, 2001).

We find strong evidence that both monetary and non-monetary incentives have an effect on CSR. In particular, we find that i) monetary incentives designed to align CEO's and shareholders' interests have a negative effect on CSR, ii) incoming CEOs, who have a longer time horizon and a need for legitimacy in the eyes of all stakeholders, and older CEOs, who have less career concerns, are more likely to invest more in CSR, and finally iii) powerful and entrenched CEOs positively affect the level of CSR.

We build upon prior research in three ways. First, we provide a theoretical contribution to the existing literature (e.g. Mahoney and Thorne 2005, 2006; Deckop et al. 2006; Frye et al. 2006) by suggesting that the CEO's compensation scheme is not the only driver of managerial attention to specific 
objectives. Although compensation is a visible and fundamental mechanism that directs managerial attention to specific objectives, previous research has failed to consider that other incentives for the CEO, such as career concerns, turnover, power and entrenchment, might be affecting CSR-related decisions. These types of non-monetary personal incentives may drive the CEO's decisions with regards to CSR and thus reinforce or substitute the effect of monetary incentives. Second, we provide an operational contribution, as we extend the analysis beyond the annual flow of incentives by also considering the changes in the value of the CEO's portfolio of stocks and options. According to Core et al. (2003), it is not possible to determine whether an executive has an appropriate level of incentives by only examining newly granted restricted stock and options in a given year because stock and options incentives are properly measured only by considering the equity portfolio of the CEO. Thus, our new focus represents a key contribution over prior work (e.g. Mahoney and Thorne 2005, 2006) that only examined the effect of new option and stock grants on CSR and thus has not allowed definite conclusions to be drawn on the issue. Third, our study brings in a methodological contribution. We show that there are important econometric issues to deal with when investigating the relationship between CEO's compensation structure and CSR. Indeed firms might jointly determine both the compensation and the CSR level, and therefore the ordinary least squares (OLS) estimators may be biased in the presence of this endogenous relationship. This problem might drive the non-significant associations found in previous studies (e.g. Mahoney and Thorne, 2006; McGuire et al., 2003). We propose the use of a set of instruments, which appear to be particularly suitable for examining the effect of executive compensation on CSR.

The paper is structured as follows: in the next section, we present the background and motivation for our study. In section 3 we develop our research hypotheses. Section 4 describes the sample selection and variables measurement; section 5 provides the empirical design and presents the results. The final 
section summarizes the results, discusses the implications of our research and points out possible limitations.

\section{BACKGROUND AND MOTIVATION}

The literature has pointed out four main justifications to explain why companies may engage in CSR (Porter and Kramer 2006, p. 81-82): 1) moral obligation, 2) sustainability, 3) license to operate, and 4) reputation. The moral argument claims that companies have a duty to be good citizens and to "do the right thing". Specifically firms are asked to pursue their success by respecting people, communities and the natural environment. The sustainability argument, instead, asks firms (but in general more the present generation) to meet their own needs without compromising future generations' ability to meet their own needs. Relating to the license to operate notion, this highlights the fact that every company needs the tacit or explicit permission to do business from a large array of stakeholders such as governments and local communities. As a consequence CSR is viewed as a useful tool for gaining such legitimacy. Finally, the last argument suggests that firms may benefit from CSR in terms of enhanced reputation thus improving their image and strengthening their brand.

A related strand of research brings CEO's monetary incentives into the broad picture of the determinants of CSR. The underlying intuition is that, ultimately, CSR activities and strategies are decided and executed by the CEO of the firm who is going to also consider her personal benefits and costs when deciding if, and to what extent, to engage in CSR.

Previous research, which has looked at the relationship between executive compensation and CSR (Frye et al., 2006; Mahoney and Thorne, 2005; McGuire et al. 2003), has mainly focused on CEO’s flow compensation. The arguments shared by this stream of research rely on the fact that CSR may lead the company to forgo short-term profits to invest in projects that have no immediate payoff. Especially in North America the emphasis is on shareholders' wealth maximization (Fama, 1980) and thus the 
incentives for the $\mathrm{CEO}$ tend to be designed to focus managerial attention upon short-term economic performance to satisfy shareholders' objectives over the interests of other stakeholders. For example, Kochan (2002) argues that US firms have focused on maximizing shareholders value without considering the effects of their actions on other stakeholders and thus calls for a possible stakeholder oriented decision-making and strategy formulation process. Nonetheless, especially after the corporate scandals that have affected businesses worldwide, firms are under increasing pressure to be both profitable and socially responsible (Deckop et al., 2006). This debate calls for a better understanding of how managerial incentives relate to CSR decisions undertaken by firms.

Using the Kinder, Lydenberg and Domini (KLD) database, McGuire et al. (2003) investigate the relation between the different components of CEO's compensation and strong and weak corporate social performance. They fail to find any relationship amongst the components of CEO's flow compensation and strong social performance while they document a positive association between CEO's salary and long-term incentives ${ }^{1}$, and weak social performance. In a related study, Mahoney and Thorne (2005) focus on Canadian firms and find very different results: they document a negative relationship between long-term compensation and weak CSR activities but a positive relationship between long-term compensation and CSR. The authors thus claim that firms may use long-term compensation to mitigate product/environment weaknesses. Mahoney and Thorne (2006) suggest that the results in McGuire et al. (2003) might be driven by the U.S. institutional environment. Thus, they conduct their study in a Canadian setting (culturally similar to the U.S. but with important differences in the institutional context) and they find that stock options are significantly related to CSR strengths, providing evidence that the institutional environment might influence the importance of these associations. Finally, Frye et al. (2006) compare CEO's compensation amongst socially responsible (SR) firms and non-SR firms. They find that the link between CEO pay and firm performance is weaker for SR firms and that these firms provide CEOs with higher base salaries. 
We directly build on this research framework and aim at expanding the set of CEO's incentives that have been linked to CSR in two directions: firstly, we do not limit the analysis of CEO's monetary incentives to flow compensation but we focus on incentives deriving from changes in the value of her portfolio of stocks and options; secondly we introduce a set of non-monetary incentives that may shape the CEOs' decisions to invest in CSR. Specifically, we model CSR decisions as a function of CEO's equity incentives, annual bonuses, career concerns, incoming/departing CEOs, and power and entrenchment using the following research function:

$$
C S R=f(C E O \text { 's Monetary Incentives, CEO's Non-Monetary Incentives } \mid \text { Firm's Characteristics) }
$$

\section{HYPOTHESES DEVELOPMENT}

\section{Monetary incentives}

Equity incentives are defined as the variation in executive's wealth caused by a change in stock price and they therefore measure the strength of CEO's incentives to increase the value of firm's stock (Core et al., 2003). A key point in analyzing equity incentives is that executive incentives from stock and options are properly measured by portfolio incentives and it is not possible to determine the level of incentives by only examining newly granted restricted stock and options in a given year (see Core et al., 2003 and Yermack, 1995). In fact, Core and Guay (2002) show that the correlation between newly granted incentives and previously held portfolio incentives is low. These considerations are extremely important in our research framework because they suggest that previous contributions which only focused on new option and stock grants when analyzing the impact of CEO's compensation on CSR do not allow definite conclusions to be drawn on the issue. The role of CEO's equity incentives on CSR is difficult to predict ex-ante. In fact, by linking CEO's personal wealth to company's stock price, equity incentives make the CEO willing to undertake only investments they deem useful to increase stock price. Therefore the interests of stakeholders, different to those of shareholders, will enter the utility 
function of highly incentivized executives only if they are expected to lead to an increase in shareholder value. As long as CSR increases a firm's legitimacy and improves its reputation it may contribute to an increase in future shareholder value but, on the other hand, it requires non-trivial investments and costs that may cause lower profits and worse stock performance. As a consequence, given that the impact of equity incentives on CSR is difficult to predict ex-ante, we state the following non-directional hypothesis:

H1: CEO's equity incentives are associated with CSR

The second monetary incentive we include in the analysis is the annual bonus. Annual bonuses have the role of linking CEO's pay to the firm's current performance in an attempt to motivate executives to take decisions that increase the firm's profits. A potential pitfall of this compensation component is the fact that when the total compensation is tightly link to current profits, the CEO may take short-term oriented decisions that boost current profits but are detrimental for the firm's future value. CSR could be a potential source of conflict for a CEO with a high annual bonus since CSR activities may require high investments in the current period that are not immediately rewarded, thus decreasing annual profits. As noted by McGuire et al. (2003), a major motivation for less socially responsible actions is to improve the short-term bottom line for two reasons: the manager is responsible for the achievement of financial and strategic, rather than social, objectives (Murphy, 2000) and the bonus component signals a "performance-driven corporate orientation that may influence managerial decision making" (McGuire et al., 2003, p. 344). As a consequence we expect that the CEO's annual bonus is negatively related to CSR because the CEO is more concerned to increase current profits rather than to engage in activities that benefit other stakeholders.

H2: CEO's annual bonus is negatively associated with CSR 


\section{Non-Monetary Incentives ${ }^{2}$}

As regards non-monetary incentives our research function focuses on incoming/departing CEOs, career concerns and power and entrenchment.

The main effect of CEO's turnover is a change in the executive's time horizon. Specifically, a departing CEO knows that she will be moving from the firm the following year and therefore she may engage in opportunistic behavior during the last year of tenure. For instance, Dechow and Sloan (1991) examine a sample of firms in industries that have significant ongoing $R \& D$ activities and show that CEOs spend less on R\&D during their final years in office. With reference to CSR activities, the departing CEO could opportunistically decrease this type of investment given the reduced incentives to assure legitimacy and the good reputation of the firm. On the other hand, it could be argued that an incoming CEO has the longest possible time horizon since she will (hopefully) stay with the firm for a long time. As a consequence it would make sense for an incoming CEO to engage in CSR activities because she could gain legitimacy in the eyes of stakeholders and reap the benefits in future years. Therefore we state the following hypothesis:

H3: A departing (incoming) CEO is less (more) likely to engage in CSR

The second non-monetary incentive that we conjecture will influence CSR is CEO's career concerns. Specifically, our predictions are rooted in Holmström's (1999) model, which shows that career concerns are greater for young versus old managers. Holmström (1999) developed a model in which learning about a qualified measure of the manager's talent and ability occurs through the observation of the manager's output. The precision of information about the manager's ability typically increases as time goes on; thus the market puts more weight on the output observations during the early stage of the executive's career. In fact, at the beginning of the executive's career the market has less information and observable results are more important for inferring the manager's "type". Since young executives 
have to deliver positive observable outcomes to the market, they are likely to have a focus on boosting short-term performance that can be immediately incorporated by the market and used to positively assess their "type". Therefore, they might be less willing to make long-term investments that deliver positive observable outcomes only in the future. As a consequence, assuming that CSR activities are a long-term investment, young managers may prefer to forego CSR projects and to focus on delivering high and constant profits in the short-term. On the contrary, as CEOs get older and feel less pressure from the market in terms of career concerns, they may be more willing to address the concerns of a wide array of stakeholders independently of the immediate effect on the firm's profits. This prediction is also consistent with literature suggesting that age is a factor in determining values, as younger managers tend to assign less importance to trust and honor, and more to money and advancement, than older executives (e.g. England, 1978; Barnett and Karson, 1989). More recently, literature has shown that older CEOs have a stronger motivation to "give back" to their communities (McCuddy and Cavin, 2009) and that, thanks to the accumulation of social expertise and greater cultural intelligence, older CEOs are more inclined to implement diversity practices than younger CEOs (Ng and Sears, 2012). Therefore we state the following hypothesis:

H4: CEO's age is positively associated with CSR

The last executive characteristic analyzed is CEO's power and entrenchment. More powerful and entrenched CEOs fail to experience discipline from the full range of corporate governance and control mechanisms (Berger et al., 1997). According to Surroca and Tribò (2008) entrenched managers may collude with non-shareholder stakeholders in order to reinforce their entrenchment strategy. These authors point out three arguments to justify CEOs commitment to CSR. First, there is a reputation issue as stakeholders might have the power to penalize top executives by engaging in boycott or media campaigns. Second, by colluding with stakeholders, CEOs reduce the firm's attractiveness to potential 
raiders. Finally, Surroca and Tribò (2008) argue that stakeholders' satisfaction and CSR-oriented strategy can be used as entrenchment mechanisms to counter-balance the impact of internal corporate control mechanisms. Moreover, entrenched CEOs suffer less market pressure and therefore may not behave "myopically" by cutting all investments that do not ensure short-term performance increases (see Stein, 1989). Thus, we expect a positive relationship between CEO's power and entrenchment and CSR. Thus we state the following hypothesis:

H5: CEO's power and entrenchment are positively associated with CSR

\section{DATA}

\subsection{Sample Selection}

We base our analysis on a sample of US firms over the period 2005-2009. We compute our CEOs' incentives measures from the Execucomp dataset while we retrieve the CSR metrics from the Ethical Investment Research Services data. We start from 2,770 firm-year observations over the period 20052009 which are simultaneously covered by both datasets ${ }^{3}$. We lose 244 firm-years' observations where there is missing data for computing the full set of CEOs' incentives and a further 6 observations with missing data on Compustat for computing the control variables. Therefore we end up with a final sample of 2,520 firm-year observations for 597 unique firms. Table 1 summarizes the sample selection process and the observations' distribution over the time period analyzed.

INSERT TABLE 1 ABOUT HERE

\subsection{Variable Measurement}




\section{Corporate Social Responsibility}

CSR data are obtained from EIRIS who specialize in the measurement of corporate social responsibility against a consistent and objective set of criteria, principally for investors' use. On the basis of the theoretical contribution of Carroll (1979) and empirical work carried out by Johnson and Greening (1999) and Cox et al. (2004) on the multidimensional nature of CSR, we make use of both an aggregate CSR measure that takes into consideration a range of important issues across companies and three constituent constructs that reflect specific dimensions of the overall CSR measure (Brammer and Pavelin, 2004). The three constituents (CSR attributes) we consider are: community, employees and environment ${ }^{4}$. The EIRIS measure for community performance is measured using a single variable (commitment to community or charitable work). The EIRIS employee performance measure encompasses six aspects: health and safety systems, training and development systems, systems for good employee relations, practices for job creation and security, equal opportunities policies and equal opportunities systems. The EIRIS environmental performance measure comprises three elements: environmental impact improvements, environmental management systems, environmental policy and commitment 5 .

Relying on the method adopted by Brammer et al. (2006) and Cox et al. (2007), who base their work on Graves and Waddock (1994), we transform the EIRIS text-grade rating for each measure into a number-grade rating starting at 1 and increasing with better performance. The community measure has four text-grade ratings, each employee aspect has three text-grade ratings and each environment element has five text-grade ratings, all of which were transformed into integer scales beginning with 1 and ending in 4, 3 and 5 respectively. To arrive at a single measure for community, employees and environment CSP attributes, we sum the number-grade ratings for each attribute. Therefore we obtain a community score out of 4 , an employee score out of 18 and environment score out of 15 . The employee performance measure and the environment measure have a Cronbach's Alpha of 0.82 and 0.91 
respectively ${ }^{6}$.

To arrive at a single measure for employees (EMPLOYEES), environment (ENVIRONMENT) and community (COMMUNITY) CSR attributes, we calculate the standardized metrics for each CSR attribute as follows:

$$
\text { Standardized CSR attribute }{ }_{i t}=\left(\text { CSR attribute score }{ }_{i t}-\min \right) /(\max -\min )
$$

Our aggregate measure of social responsibility (CSR) is the sum of the three scores having standardized each on a 0 to 1 grading, therefore it varies from 0 to $3^{7}$.

\section{Equity Incentives}

Core et al. (2003) emphasize executive incentives from stocks and options are properly measured only considering portfolio incentives. In fact, the amount of newly granted restricted stocks and stock options is not sufficient for evaluating the amount of incentives the executive is provided with (Yermack 1995). We measure CEO's equity incentives (EQUITY_INCENTIVE) by means of the incentive ratio computed as in Bergstresser and Philippon (2006). We start by computing the dollar change in the value of CEO's stock and option holdings that would come from a one-percentage point increase in the company stock price (CEO_ONEPCT) using the following formula:

$$
\text { CEO_ONEPCT } T_{i t}=0.01 * \text { PRICE }_{i t} *\left(C E O \_S H A R E S_{i t}+C E O \_D E L T A_{i t} * C E O \_O P T I O N S_{i t}\right)
$$

In the above specification, for any fiscal year $t$ and firm $i$, PRICE is the fiscal year-end company share price, CEO_SHARES is the number of shares held by the CEO as at the fiscal year-end, CEO_OPTIONS is the number of options held by the CEO as at the fiscal year-end and CEO_DELTA is an estimate of the delta of the CEO's option portfolio.

In order to calculate CEO_DELTA we follow Core and Guay (2002)'s methodology for estimating the delta of executives' option portfolio. In particular, CEO's options are divided into three groups (options awarded during the year, options awarded in previous years but not yet exercisable and options granted 
in previous years and currently exercisable) and separate estimates of the delta are computed ${ }^{8}$. Core and Guay (2002) show that their proxy captures more than $99 \%$ of the variation in option portfolio value and sensitivity. Starting from 2006, Execucomp reports all the necessary data for directly computing the delta of CEO's option portfolio thus eliminating the need to use Core and Guay (2002)'s approximation. Secondly, the measure of incentive computed in (1) is standardized by the amount of cash compensation ${ }^{9}$ received by the CEO during the fiscal year as in Bergstresser and Philippon (2006). Therefore we compute CEO's incentive ratio as follows:

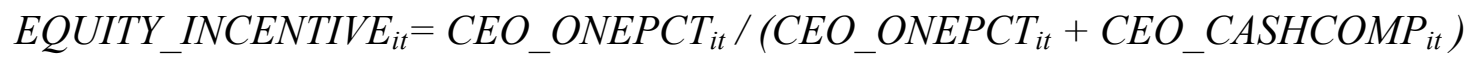

\section{CEO's Annual Bonus}

We create a variable (BONUS), which is the log transformation of CEO's annual bonus as disclosed in Execucomp.

\section{Incoming and Departing CEOs}

To investigate the effect of incoming and departing CEOs we create two dummy variables. The first variable (FIRST_YEAR) takes on a value of 1 if the CEO served in the company for the first year, zero otherwise while the second dummy (LAST_YEAR) takes on a value of 1 in the last year of CEO's tenure, zero otherwise.

\section{CEO Career Concerns}

Following Demers and Wang (2010), we proxy for CEO's career concerns by using CEO's age as disclosed in Execucomp (AGE). As pointed out by the Demers and Wang (2010), this is consistent with the Holmström $(1982,1999)$ model which suggests that career concerns are greater for younger versus older managers since they have to influence the market's beliefs about their ability. Thus a positive 
(negative) coefficient on age means that the CEO with higher career concerns engages less (more) in CSR.

\section{CEO Power and Entrenchment}

For creating our proxy of CEO's power and entrenchment we consider both CEO's tenure and CEO's duality. Following Carter et al. (2007) we measure tenure as the number of years the CEO has held that position (calculated from Execucomp variable "becameceo"), or if missing, the number of years an executive has been with the firm (calculated from Execucomp variable "joined_co"). We then create a dummy variable (TENURE), which takes on a value of 1 if CEO's tenure is greater than, or equal to three years, and zero otherwise. This is consistent with Fredrickson et al. (1988) who argue that early vulnerability occurs when CEO tenure is less than, or equal to, three years, while after three years CEOs start gaining power and becoming more entrenched. As regards the CEO's duality we create a dummy variable (DUALITY), which takes on the value of 1 if the CEO is also the chair of the board of directors. We then conduct a factor analysis between CEO's tenure and CEO's duality and retain the first factor as a proxy for CEO's power and entrenchment (POWER_ENTR).

\section{Controls}

When investigating our research questions we control for several other related characteristics. Specifically, $\mathrm{P}_{-}$IND is a dummy variable that takes on the value of 1 (zero) if the proportion of independent non-executives on the board is more (less) than $33 \%$ as disclosed in the EIRIS database; SIZE is the natural logarithm of the firm's total assets; ROA is operating income divided by total assets; LEVERAGE is the firm's leverage computed as total debt divided by total assets; B_M is the book-to-market ratio; IND is a dummy variable that takes on the value of 1 if the firm belongs to either 
an environmentally or socially sensitive industry (mining, metal, oil, gas, chemical, pharmaceutical, paper, alcohol, defense, utilities).

\subsection{Descriptive Statistics and Correlations}

Table 2 presents descriptive statistics for the variables in the analysis. As is usually the case when dealing with the Execucomp database, our final sample is comprised of large and profitable firms with high growth opportunities. The mean CSR score is almost 1 , (which is relatively low given a maximum of 3) and the highest performances are recorded in terms of community CSR. The average CEO has a substantially high equity incentive ratio $(0.34)$, holds his position for more than three years, is also the chair of the board and is 55 year old. All values appear to be in reasonable ranges and are comparable with those of previous research.

\section{INSERT TABLE 2 ABOUT HERE}

Table 3 presents Pearson correlation coefficients amongst the variables of interest. As expected, large and profitable firms provide the CEO with higher levels of equity incentives whilst in the presence of smaller growth opportunities CEO's wealth is less tightly linked to shareholder value. Moreover, older and more entrenched CEOs tend to receive higher compensation thus showing a positive correlation with equity incentives. The different CSR metrics are highly correlated with each other consistent with the fact that they capture different aspects of the same construct. Overall correlations appear to be within reasonable ranges and comparable with those of previous studies.

INSERT TABLE 3 ABOUT HERE 


\section{EMPIRICAL ANALYSIS}

In order to investigate our first research question we fit the following OLS regression with firm clusteradjusted standard errors and year fixed effects:

$$
\begin{aligned}
\mathrm{CSR}_{\mathrm{i}, \mathrm{t}}=\beta_{0} & +\beta_{1} * \mathrm{EQUITY}_{-} \text {INCENTIVE }_{\mathrm{i}, \mathrm{t}}+\beta_{2} * \mathrm{BONUS}_{\mathrm{i}, \mathrm{t}}+\beta_{3} * \mathrm{FIRST}_{-} \mathrm{YEAR}_{\mathrm{i}, \mathrm{t}}+\beta_{4} * \mathrm{LAST}_{-} \mathrm{YEAR}_{\mathrm{i}, \mathrm{t}} \\
& +\beta_{5} * \mathrm{AGE}_{\mathrm{i}, \mathrm{t}}+\beta_{6} * \text { POWER_ENTR }_{\mathrm{i}, \mathrm{t}}+\beta_{7} * \mathrm{P}_{-} \mathrm{IND}_{\mathrm{i}, \mathrm{t}}+\beta_{8} * \mathrm{SIZE}_{\mathrm{i}, \mathrm{t}}+\beta_{9} * \mathrm{ROA}_{\mathrm{i}, \mathrm{t}}+\beta_{10} * \\
& \text { LEVERAGE }_{\mathrm{i}, \mathrm{t}}+\beta_{11} * \mathrm{~B}_{-} \mathrm{M}_{\mathrm{i}, \mathrm{t}}+\beta_{12} * \mathrm{IND}_{\mathrm{i}, \mathrm{t}}+\varepsilon_{\mathrm{i}, \mathrm{t}}
\end{aligned}
$$

For any firm i and year t, CSR takes on the value of either CSR, COMMUNITY, EMPLOYEE, or ENVIRONMENT; and all the other variables are as previously described.

Table 4 presents estimated results from (3) using the CSR metrics. Our models present relatively high values of the R-squared (it ranges from $13.3 \%$ in model 2 to $27.8 \%$ in model 1). All the F-statistics have p-values less than 0.000 and they range from 9 (in the model with COMMUNITY as dependent variable) to 26 (the model with $C S R$ as dependent variable), thereby suggesting that our models are significant in explaining variation across our CSR metrics.

In column (1) the significant coefficient on EQUITY_INCENTIVE supports H1 and the negative sign indicates that when CEO's wealth is more strongly related to stock price changes, they engage less in CSR activities. This suggests that whilst executives might deem CSR to be potentially beneficial for stakeholders broadly defined, they do not view it as such for shareholders. Therefore when their private interests are strictly related to those of shareholders (i.e. increasing stock price) they move resources from CSR investments to other projects that they assess as having a greater impact on share price. Furthermore, the significant coefficient of BONUS supports H2: the amount of annual bonuses is negatively related to CSR activities thus confirming CEOs' belief that CSR activities may be detrimental to the firm's current profits. In line with the predictions of $\mathrm{H} 3$, incoming CEOs are associated with higher scores on CSR; this may be due to the fact that they are new to the company (at least in that position) and need to gain legitimacy towards a broad group of stakeholders. Moreover, 
incoming CEOs have the longest time horizon and may anticipate that all long-term investments will produce the expected benefits during their tenure. On the contrary, we do not find evidence that CEOs behave opportunistically in the last year of tenure by decreasing the level of CSR. The coefficient for age is positive but not significant; therefore we do not find support for H4. Thus age concerns do not appear to affect the level of CSR indicating that both young and old CEOs engage in CSR activities to the same extent. Finally, results on POWER_ENTR suggest that more powerful and entrenched CEOs engage to a larger extent in CSR. This is consistent with the fact that these managers feel the market pressure less and therefore may address concerns and issues that go beyond shareholders' financial interests, in line with the expectations outlined in $\mathrm{H} 5$.

We also find some interesting results with regard to our control variables. The proportion of independent directors ( $\left.\mathrm{P}_{-} \mathrm{IND}\right)$ is significantly and positively related to CSR, indicating that more independent boards are more likely to serve stakeholders' CSR interests. We also have evidence that there is a positive association between company size and CSR, suggesting that bigger companies which are more visible and thus under greater pressure on CSR issues - are more likely to perform better in terms of CSR. Similarly, we find that companies in socially or environmentally sensitive industries - which are more exposed to societal pressure and legitimacy issues - are more likely to perform better in terms of CSR. Finally, we find a negative coefficient for the book to market ratio and leverage. Thus, companies with low growth opportunities and high leverage invest relatively less in CSR compared to companies facing high growth prospects and having a low debt financing structure.

\section{INSERT TABLE 4 ABOUT HERE}

Table 4 also disaggregates CSR variables into the three components: community, employee and environment CSR. This makes it possible to understand if the results presented in the previous analysis are homogeneous across the different CSR dimensions or if, on the contrary, the effects documented 
are stronger for some of them. All the coefficients that are significantly related to total CSR also maintain their sign for the disaggregated metrics even if their statistical significance changes. Specifically, the results on CEO's equity incentives are stronger for employee and environment CSR while the level of equity incentives the CEO is provided with appears to have less effect on community CSR activities. In a similar vein, the results on incoming CEOs (FIRST_YEAR) and power and entrenchment are also supported for employee and environment CSR but not for community CSR, thus suggesting that the effect of CEO's private benefits is less accentuated in community related CSR activities. Finally, the coefficient for age is not significant for any of the disaggregated CSR measures.

\subsection{Additional Analyses}

An important issue with regards to OLS models is that the estimation might suffer from omitted variables: firms might jointly determine CEO's compensation structure (EQUITY_INCENTIVE and BONUS) and CSR outcomes, therefore some unobservable variables might affect both the compensation structure and CSR such as, for example, CEO's personal characteristics. Moreover, CSR-related indicators might be included as performance targets in the incentive schemes of managers. Evidence of such practice is provided by Rodrigue et al. (2012), who find that $33 \%$ of their US sample firms include environmental performance indicators in executive compensation contracts. Thus, potential reverse causality bias might be another source of endogeneity. This endogenous relationship might induce OLS estimators to be biased.

In order to address the concern about endogeneity we use two approaches: a three stage least squares with simultaneous equations (3SLS) and two-stage least squares with instrumental variables (2SLS). The use of a system estimator (3SLS) theoretically contains a potential gain in efficiency, which makes coefficient estimates more precise. However this greater efficiency comes at a cost (Larcker and Rusticus, 2010): a limited-information estimator such as a 2SLS model using instrumental 
variables has the advantage that the estimates in the second stage are not affected even when the first stage is mis-specified. Thus we report results using both approaches.

A common problem in accounting and governance research is to find truly exogenous variables that are also correlated with the endogenous regressors (Larcker and Rusticus, 2010), in other words instruments have to be valid and strong. An instrument is defined as valid when it is associated with the endogenous regressor but uncorrelated with the disturbance term in the equation of interest and it is said to be strong when it has a high correlation with the troublesome explanatory variable. Invalid instruments lead to both biased and inconsistent estimators, whilst weak instruments are likely to produce estimates that are centered on the corresponding OLS estimate and thus may be biased as well. We use three instruments for our two endogenous variables (equity incentives and bonus): LSALARY, EQUITY_IV, BONUS_IV. Our first instrument (LSALARY) is the base salary: on the one hand, base salaries tend to be fixed and thus should not have an effect on CSR, but they are also part of the compensation package and thus affect both equity incentives and bonus. We expect a negative (positive) relation between equity incentives (bonus) and CEO's base salary because equity compensation is used as a substitute for cash compensation while bonuses are usually computed as a percentage of CEO’s base salary (Murphy, 1999).

Our second instrument (EQUITY_IV) is the yearly mean of the equity incentives provided to the CEOs of all firms belonging to the 2-digits SIC code of firm $i$, excluding the equity incentives provided to the CEO of firm $i$. Similarly, our third instrument (BONUS_IV) is the yearly mean of the annual bonus provided to the CEOs of all firms belonging to the 2-digits SIC code of firm $i$, excluding the bonus provided to the CEO of firm $i$. The underlying motivation for using these two instruments is that compensation structures tend to be correlated inside given industries (Murphy, 1999) but arguably are not related to the CSR of a specific firm. 
We run a series of tests to verify the validity and strength of our instruments. First, given that the bias is proportional to the degree of over-identification (Angrist and Krueger, 2001) and the difficulties in finding truly exogenous variables, we perform a Sargan-Hansen test, following Murray (2006). The null hypothesis for this test is that the instruments are valid in the sense that they are not correlated with the errors in the estimated equation. In our case, the Hansen's J Chi2(1) is equal to 0.006 and the pvalue is 0.940 . Thus, we do not reject the null hypothesis and conclude that the over-identifying restriction is valid. Following Larcker and Rusticus (2010), after testing for over-identifying restrictions, we perform the Hausman test to check that the specified endogenous regressors cannot be treated as exogenous. The Hausman test leads to strong rejection of the null hypothesis that equity incentives and bonus are exogenous $(\mathrm{p}$-value $=0.000)$. Finally, using the Stock-Yogo test, we analyze whether the instruments are weak (Murray, 2006; Larcker and Rusticus, 2010). The F-statistic is equal to 15.996 and thus we feel comfortable in rejecting the null hypothesis of weak instruments.

Estimated results are reported in Table 5 and they strongly corroborate findings from the main analysis. In contrast with the results from the OLS models, we find that age concerns appear to affect the level of all our CSR measures (supporting H4), indicating that older CEOs, with lower career concerns, are more likely to engage in CSR activities than younger CEOs. This highlights the importance of considering CEO's non-monetary incentives stemming from career concerns when investigating the determinants of CSR. Moreover, this additional analysis shows that all the significant coefficients are less biased towards zero than in the OLS regressions. For example, the coefficient for age - which was not significant in the OLS estimation - is now highly significant ${ }^{10}$. This suggests that relationships, which the previous literature found were not significant, might have been driven by unresolved endogeneity problems. Thus, we highlight the importance of addressing endogeneity issues with the proper econometric models in order to make the correct inferences from empirical analysis. 


\section{INSERT TABLE 5 ABOUT HERE}

As a robustness test (un-tabulated), we run the analysis using the lagged value of CEO's monetary and non-monetary incentives. With the exception of the result for incoming CEOs (FIRST_YEAR), all findings documented in the previous analyses are confirmed, thus corroborating the support for our hypotheses. The fact that the coefficient of FIRST_YEAR is no longer significant in this alternative model specification is consistent with the fact that a change in CEO affects CSR in the year in which it takes place.

To make sure that results are not driven by the specific way in which we measure CSR, we also use an alternative approach and estimate our model using data from KLD Research and Analytics, Inc. KLD is an independent company which rates firms across six CSR areas: community, diversity, employee relations, environment, human rights, and product quality and safety. For each area, KLD analysts assign strengths and concerns associated with these issues. KLD data have been extensively used in the management literature on corporate social and environmental performance (see, e.g., Waddock and Graves 1997; Johnson and Greening 1999; Hillman and Keim 2001) as well as in recent social and environmental accounting research (see, e.g., Cho et al. 2006; Cho and Patten 2007; Cho et al. 2010; Cho et al. 2012). We therefore estimate model (3) on page 17 through 3SLS using KLD strengths scores as the dependent variable and controlling for KLD concerns among the regressors. Un-tabulated results show that all coefficients (except for POWER_ENTR, $p$-value $=0.2$ ) maintain their sign and are statistically significant when also using this alternative approach, thus providing some assurance that the main results documented in the analysis are not driven by the specific way in which CSR is measured.

\subsection{Adjusted predictions and marginal effects}


In this section we analyze the economic impact of our results to provide insights on their practical relevance. To do this, we compute adjusted predictions and marginal effects using coefficient estimates from Table 5, Column 1. Specifically, we compute the percentage change in the dependent variable that would result from a specified change in an independent variable, holding the value of the other independent variables at their mean value.

In our sample, as Table 2 (descriptive statistics) shows, CEOs with relatively low equity incentives are characterized by an incentive ratio of $0.148 \quad\left(25^{\text {th }}\right.$ percentile of the distribution of EQUITY_INCENTIVE). The computation of adjusted predictions shows that, when the level of equity incentive doubles (i.e. it increases from 0.148 to 0.296 ) the value of CSR decreases by $15 \%$, holding the other variables at their mean value. As regards bonuses, the marginal analysis shows that firms in which the CEO has a cash bonus of USD 100,000 have, on average, CSR levels that are $33 \%$ lower than firms in which the CEO does not have any bonuses. Firms in which the CEO is in the first year of tenure have CSR levels that are, on average, $18 \%$ higher than companies in which the CEO has held the position for a longer period. The effect of CEO's power and entrenchment on CSR is, however, less relevant. In fact, moving from the first to the third quartile of the distribution of the variable POWER_ENTR, the level of CSR increases by only 1\%. Finally, the results for the CEO's age indicate that companies with a 60-year old CEO present, on average, 13\% higher CSR levels than companies with a 50-year-old CEO. These results are not so high as to appear unrealistic but their magnitude suggests that the results documented in this paper are not only statistically significant but also economically important.

To understand the relative importance of the variables included in the analysis in driving CSR, we compute the percentage change in the dependent variable that would arise from a $1 \%$ change in any of the independent variables (evaluated at the mean value). The results (un-tabulated) indicate that CEO's 
age is the most important driver of CSR activities, since a 1\% change in CEO's age has the highest impact on CSR activities.

\section{CONCLUSIONS}

In this study we explore the role of CEO's monetary and non-monetary incentives in addressing CSR decisions.

Our empirical analysis provides evidence of a negative and significant relationship between CSR and CEO's equity incentives and annual bonus respectively, suggesting that when CEO's private interests are strictly related to those of shareholders (i.e. increasing stock price and accounting performance) the CEO is less likely to invest in CSR. On the contrary, an incoming CEO engages significantly more in CSR and this may be due to the fact that she is new to the company (at least in that role) and needs to gain legitimacy towards a broad group of stakeholders and/or has a longer time horizon. Moreover, we show that when the CEO has low career concerns, or the CEO is more powerful and entrenched, she engages to a larger extent in CSR. This is consistent with the fact that these managers feel the market pressure less and therefore may address concerns and issues that go beyond shareholders' financial interests. An alternative explanation is that powerful and entrenched CEOs are more likely to collude with stakeholders to "reduce a firm's attraction to potential raiders" (Surroca and Tribò, 2008, p. 749). We believe that these results are particularly relevant because CEOs are recognized to have extensive decision-making power and the ability to affect the social responsibility of a firm (Deckop et al. 2006; Kochan, 2002; Manner, 2010; Waldman et al., 2006).

Overall, our evidence suggests that CEO's decisions on CSR are not driven only by monetary incentives but also by personal non-monetary incentives that relate to the role of the executive within the firm (incoming, powerful and entrenched CEOs) and her career concerns (age). 
Our study has important implications. First, it may be useful for providing guidance to firms when designing the compensation structure for the CEO, as we show that there are many levers that can affect CEO's decisions with regards to CSR. This aspect directly stems from our theoretical contribution, which expands the set of CEO's incentives affecting CSR decisions. For instance, the fact that young managers, because of their focus on short-term performance, tend to invest less in CSR than older CEOs suggests that compensating younger CEOs with high levels of bonuses could be particularly detrimental to firms' CSR. On the contrary, since CEOs who are closer to retirement feel market pressures less and tend to invest more in CSR, the negative impact of monetary incentives on CSR investments is likely to be less severe. This should be taken into consideration by firms when designing the compensation scheme for their executives, especially if CSR has a pivotal role in the company. Second, our results confirm the prominent role of the CEO in affecting CSR, but - at the same time - highlight the complexity of the factors affecting CSR decisions. In other words, our results suggest that focusing only on CEO's monetary incentives overlooks other important drivers of CSR. Indeed, previous literature on CSR failed to consider the role of CEO's non-monetary incentives, thus providing only an incomplete picture of how CEOs take CSR-related decisions. Third, we highlight a shortcoming in the academic research in relation to an important methodological fallacy that may bias results when endogeneity is not formally considered in the research design. This last point is closely related to our methodological contribution and suggests that future research on CSR should always try to properly address endogeneity concerns in order to make it possible to infer robust conclusions on the topic under investigation. In the paper we propose a possible empirical strategy to be used to address this issue, but there could be others.

Like all studies, ours is not without its limitations. First of all, our sample only considers large US firms and thus our results may not hold in other settings. Furthermore, CSR is measured using a proxy and although we believe it to be reliable and accurate, it may not be capturing the true underlying 
attributes. Another important caveat is that we do not explore any related psychological drivers that might affect CEO's decisions on CSR, for example the trade-off between objective and subjective career success (Abele and Spurk, 2009). Finally, although we use an instrumental variable approach to take account of potential unobservable CEO's characteristics, it could possibly be interesting to analyze the direct effect of CEO's personal characteristics (for example, education) on CSR. This might be a fruitful avenue for future research.

\section{NOTES}

${ }^{1}$ Long-term incentives generally may include stock options, other forms of market-based compensation, and nonmarket based long term incentive plans (McGuire et al. 2003).

${ }^{2}$ Non-monetary incentives are those incentives that do not stem from the executive's compensation structure and are not linked to a monetary reward.

${ }^{3}$ EIRIS monitors the CSR performance of companies listed in the FTSE World Index. It covers 2,970 firm-year observations in the US. Execucomp covers the S\&P 1500 companies and contains over 2,872 firms. Therefore our final sample consists of all firm-year observations included in the EIRIS dataset that also have compensation data in the Execucomp dataset (2770 firm-year observations). With reference to the period analyzed in the paper, the Execucomp dataset covers more than the 90 percent of company-year observations included in the EIRIS database. Since our final sample is an intersection between companies listed in the FTSE World Index and firms listed in the S\&P 1500 Index, our inferences are mainly drawn from large and profitable firms and thus results should be interpreted with this caveat in mind.

${ }^{4}$ EIRIS measures five CSR attributes: employment, environment, community, human rights and supply chain management. Nonetheless, full information is available only for the environment, employment and community dimensions of social performance. Few data are available for human rights and supply chain management. Since including all five CSR attributes would unnecessarily restrict the sample size, the analysis is restricted to three dimensions of social performance: environment, employment and community. This approach is commonly used in papers relying on EIRIS data (see Brammer and Pavelin, 2004; Cox et al., 2004; Brammer et al., 2006; Brammer and Pavelin, 2006; Cox et al., 2007).

${ }^{5}$ EIRIS environmental performance would comprise a fourth additional item: environmental reporting. We do not consider it in our construct in order to avoid bias in our measure of environmental performance because of self-reported information (e.g. Cho and Patten, 2007; Patten, 2002)

${ }^{6}$ Cronbach's Alpha is used to measure how well a list of items measures a single latent construct. Values of Cronbach's Alpha range between 0 and 1 , with values above 0.7 commonly thought to provide a sufficient level of reliability(Hair et al. 1998).

${ }^{7}$ Throughout the paper we use the moral consensus approach described in Eabrasu (2012), since we measure CSR using the EIRIS dataset that analyzes firms' good practices assuming the existence of a moral consensus. Even if giving a moral interpretation of results is well beyond the scope of our work, we acknowledge that our framework relies on the mainstream CSR definition of good CSR practices (OECD 2001), and therefore it remains somewhat arbitrary. The use of a moral pluralism approach, even if desirable from a theoretical standpoint, would be very difficult to operationalize in an archival study such as ours. Nonetheless, results should be interpreted with this caveat in mind.

${ }^{8}$ Appendix A reports the formula used for computing the sensitivity of individual stock options to stock price.

${ }^{9}$ Cash compensation is defined as the sum of base salary and annual bonuses.

${ }^{10}$ The coefficient for age also has an important economic effect as we discuss in section 5.2 


\section{REFERENCES}

Abele, A.E. and Spurk, D. (2009). How do objective and subjective career success interrelate over time? Journal of Occupational and Organizational Psychology 82, 803-824.

Angrist, J.D. and Krueger, A.B. (2001). Instrumental variables and the search for identification: from supply and demand to natural experiments. Journal of Economic Perspectives 15(4), 69-85.

Barnett, J. H., and Karson, M.J. (1989). Managers, values, and executive decisions: An exploration of the role of gender, career stage, organizational level, function, and the importance of ethics, relationships and results in managerial decision-making. Journal of Business Ethics 8 (10), 747 771.

Berger P., Ofek, E. and Yermack, D. L. (1997). Managerial entrenchment and capital structure decisions. Journal of Finance 52 (4), 1411-1438.

Bergstresser, D., and Philippon, T. (2006). CEO incentives and earnings management. Journal of Financial Economics 80 (3), 511-529.

Brammer, S. and Pavelin, S. (2004). Voluntary social disclosure by large UK companies. Business Ethics: A European Review 13(2/3), 86-99.

Brammer, S. and Pavelin, S. (2006). Corporate reputation and social performance: The importance of fit. Journal of Management Studies 43 (3): 435-455.

Brammer, S., Brooks, C. and Pavelin, S. (2006). Corporate social performance and stocks returns: UK evidence from disaggregate measures. Financial Management 35 (3), 97-116.

Carroll, A. B., (1979). A three-dimensional conceptual model of corporate performance. Academy of Management Review 4 (4), 497-505.

Carter, M. E., L. J. Lynch, and Tuna, I. (2007). The role of accounting in the design of CEO equity compensation. The Accounting Review 82 (2), 327-357.

Cho, C.H. and Patten, D.M. (2007). The role of environmental disclosures as tools of legitimacy: a research note. Accounting Organizations and Society 32, 639-647.

Cho, C.H., Michelon G. and Patten, D.M. (2012). Impression management in sustainability reports: an empirical investigation of the use of graphs. Accounting and The Public Interest, 12(1), 16-37

Cho, C.H., Patten, D.M. and Roberts, R.W. (2006). Corporate political strategy: an examination of the relation between political expenditure, environmental performance and environmental disclosure. Journal of Business Ethics 67(2), 139-154.

Cho, C.H., Roberts, R.W., and Patten, D.M. (2010). The language of US corporate environmental disclosure. Accounting, Organizations and Society 35(4), 431-443.

Core, J., and Guay, W. (2002). Estimating the value of employee stock option portfolios and their sensitivities to price and volatility. Journal of Accounting Research 40 (3), 613-630.

Core, J.E., Guay, W. and Larcker, D.F. (2003). Executive equity compensation and incentives: a survey. Economic Policy Review 9 (April), 27-50.

Cox, P., Brammer, S. and Millington, A. (2004). An empirical investigation of institutional investors preferences for corporate social performance. Journal of Business Ethics 52(1), 27-43. 
Cox, P., Brammer, S. and Millington, A. (2007). Pension fund manager tournaments and attitude toward corporate characteristics. Journal of Business, Finance \& Accounting 34(7\& 8), 1307-1326

Dechow, P. M., and Sloan, R. G. (1991). Executive incentives and the horizon problem: An empirical investigation. Journal of accounting and Economics 14 (1), 51-89.

Deckop, J.R., Merriman, K.K. and Gupta, S. (2006). The effects of CEO pay structure on corporate social performance. Journal of Management 32(3), 329-342.

Demers. E.A. and Wang, C. (2010). The impact of CEO career concerns on accruals based and real earnings management, SSRN working paper.

Eabrasu, M. (2012). A Moral Pluralist Perspective on Corporate Social Responsibility: From Good to Controversial Practices. Journal of Business Ethics 110 (4), 429-439.

England, G. W. (1978). 'Managers and their value systems: A five-country comparative study. Columbia Journal of World Business 13 (2), 35-44.

Fama, E. F. (1980). Agency problems and the theory of the firm. The Journal of Political Economy 88(2), 288-307.

Fredrickson, J. W., Hambrick, D. C. and Baumrin, S. (1988). A model of CEO dismissal. Academy of Management Review 13(2), 255-270.

Frye, M. B., Nelling, E. and Webb, E. (2006). Executive compensation in socially responsible firms. Corporate Governance: An International Review 14 (5), 446-455.

Graves, S.B. and Waddock, S.A. (1994). Institutional owners and corporate social performance. Academy of Management Journal 37(4), 1034-1046.

Hair, J. F., Anderson, R. E., Tatham, R. L. and Black, W. C. (1998). Multivariate data analysis. 5th edition (Prentice-Hall International, Inc.).

Hillman, A., and Keim, G. (2001). Shareholder value, stakeholder management, and social issues: What's the bottom line? Strategic Management Journal 22 (2), 125-139.

Holmström, B. (1982). Managerial incentive schemes: a dynamic perspective, in Essays in Economics and Management in Honour of Lars Wahlbeck. Swenska Handelshogkolan, Helsinki. Finland.

Holmström, B. (1999). Managerial incentive problems: a dynamic perspective. Review of Economic Studies 66(1), 169-182.

Johnson, R. and Greening, D. (1999). The effects of corporate governance and institutional ownership on corporate social performance. Academy of Management Journal 42(5), 564-580.

Kochan, T.A. (2002). Addressing the crisis in confidence in corporations: root causes, victims and strategies for reform. Academy of Management Executive 16(3), 139-141.

Larcker, D.F. and Rusticus, T.O. (2010). On the use of instrumental variables in accounting research. Journal of Accounting and Economics 49, 186-205

Mahoney, L., and Thorne, L. (2005). Corporate social responsibility and long-term compensation: Evidence from Canada. Journal of Business Ethics57 (3), 241-253.

Mahoney, L., and Thorne, L. (2006). An examination of the structure of executive compensation and corporate social responsibility: a Canadian investigation. Journal of Business Ethics 57 (3), 241253. 
Manner, M. (2010). The impact of CEO characteristics on corporate social performance. Journal of Business Ethics 93(0), 53-72.

McCuddy, M. K., \& Cavin, M. C. (2009). The demographic context of servant leadership. Journal of the Academy of Business and Economics, 9(2), 29-139

McGuire, J., Dow, S. and Argheyd, K. (2003). CEO incentives and corporate social performance. Journal of Business Ethics 45(4), 341-359.

Moore, G. (2001). Corporate social and financial performance: an investigation in the U.K. supermarket industry. Journal of Business Ethics 34(3-4), 299-315.

Murphy, K. (1999). Executive compensation, in O. Ashenfelter and D. Card (eds.), Handbook of Labor Economics. New Holland, Amsterdam. The Netherlands.

Murphy, K. (2000). Performance standards in incentive contracts. Journal of Accounting and Economics 30(3), 245-278.

Murray, M.P. (2006). Avoiding invalid instruments and copying with weak instruments. Journal of Economic Perspectives 20(4), 11-132.

Ng, E.S. and Sears, G.J. (2012). CEO leadership styles and the implementation of organizational diversity practices: moderating effects of social values and age. Journal of Business Ethics 105(1), 41-52.

OECD. (2001). Corporate social responsibility: Partners for progress. Paris: OECD.

Patten, D.M. (2002). The relationship between environmental performance and environmental disclosure: a research note. Accounting Organizations and Society 27, 763-773.

Porter, M. E., and Kramer, M.R. (2006). The link between competitive advantage and corporate social responsibility. Harvard business review 84 (12), 78-92.

Rodrigue, M., Magnan, M and Cho, C.H. (2012). Is environmental governance substantive or symbolic? An empirical investigation. Journal of Business Ethics forthcoming. DOI: 10.1007/s10551-012-1331-5.

Stein, J.C. (1989). Efficient capital markets, inefficient firms: a model of myopic corporate behaviour. Quarterly Journal of Economics 104(4), 655-669.

Surroca, J. and Tribò, J.A. (2008). Managerial entrenchment and corporate social performance. Journal of Business Finance and Accounting 35(5-6), 748-789.

Waddock, S. A. and Graves, S. B. (1997). The corporate social performance - financial performance link. Strategic Management Journal 18(4), 303-319.

Waldman, D. A., D. S. Siegel, and M. Javidan. 2006. Components of CEO transformational leadership and corporate social responsibility. Journal of Management Studies 43 (8), 1703-1725.

Yermack, D. (1995). Do corporations award CEO stock options effectively? Journal of Financial Economics 39 (2-3), 237-269. 
Table 1. Sample selection and distribution

\begin{tabular}{|c|c|c|c|c|c|}
\hline Firm-year observations covered by EIRIS and Execucomp datasets & 2,770 & Year & Freq. & Percent & Cum. \\
\hline & & & & & \\
\hline Missing observations on CEO's incentives & 244 & 2005 & 422 & 16.75 & 16.75 \\
\hline Missing observations on control variables & 6 & 2006 & 410 & 16.27 & 33.02 \\
\hline Total firm-years & 2,520 & 2007 & 541 & 21.47 & 54.48 \\
\hline \multirow[t]{2}{*}{ Unique firms } & $\mathbf{5 9 7}$ & 2008 & 579 & 22.98 & 77.46 \\
\hline & & 2009 & 568 & 22.54 & 100 \\
\hline
\end{tabular}


Table 2. Descriptive statistics

\begin{tabular}{lrrrrr}
\hline & N & Mean & SD & p25 & p50 \\
CSR & 2520 & 0.976 & 0.647 & 0.503 & 0.913 \\
COMMUNITY & 2520 & 0.460 & 0.348 & 0.000 & 0.667 \\
EMPLOYEE & 2520 & 0.282 & 0.173 & 0.170 & 0.250 \\
ENVIRONMENT & 2520 & 0.235 & 0.287 & 0.000 & 0.080 \\
EQUITY_INCENTIVE & 2520 & 0.339 & 0.246 & 0.148 & 0.286 \\
BONUS & 2520 & 2.198 & 3.330 & 0.000 & 0.000 \\
FIRST_YEAR & 2520 & 0.114 & 0.318 & 0.000 & 0.000 \\
LAST_YEAR & 2520 & 0.089 & 0.285 & 0.000 & 0.000 \\
AGE & 2520 & 55.79 & 6.40 & 52.00 & 56.00 \\
TENURE & 2520 & 0.69 & 0.46 & 0.00 & 1.00 \\
DUALITY & 2520 & 0.68 & 0.47 & 0.00 & 1.00 \\
P_IND & 2520 & 0.906 & 0.292 & 1.000 & 1.000 \\
SIZE & 2520 & 9.386 & 1.314 & 8.432 & 9.232 \\
ROA & 2520 & 0.103 & 0.082 & 0.050 & 0.092 \\
LEVERAGE & 2520 & 0.614 & 0.209 & 0.471 & 0.613 \\
B_M & 2520 & 0.506 & 0.401 & 0.251 & 0.418 \\
IND & 2520 & 0.189 & 0.391 & 0.000 & 0.000
\end{tabular}

\begin{tabular}{ll}
\hline CSR & EIRIS overall CSR measure \\
COMMUNITY & EIRIS community-related CSR measure \\
EMPLOYEE & EIRIS employee-related CSR measure \\
ENVIRONMENT & EIRIS environment-related CSR measure \\
EQUITY_INCENTIVE & Long-term incentives: dollar change in the value of CEO's stock and option ho \\
& would come from a one percentage point increase in the company stock price ( \\
& Bergstresser and Philippon, 2006) \\
& Short-term incentives: log transformation of CEOs' annual bonus \\
BONUS & Incoming CEO: dummy variable takes value of 1 if the CEO served in the com \\
FIRST_YEAR & the first year, zero otherwise \\
& Departing CEO: dummy variable takes value of 1 in the last year of the CEO's \\
LAST_YEAR & zero otherwise \\
& Career concerns: age of the CEO \\
AGE & CEO's tenure: number of years the CEO has held that position \\
TENURE & CEO's duality: dummy variable takes value of 1 if CEO is also the chairman of \\
DUALITY & zero otherwise \\
& Power and Entrenchment: factor analysis between the CEOs' tenure and the CF \\
POWER_ENTR & Board independence: dummy variable takes on the value of 1 (zero) if the prop \\
P_IND & independent non-executives on the board is more (less) than 33\% \\
SIZE & Firm size: natural logarithm of total assets \\
ROA & Firm operating profitability: operating profit divided total assets \\
LEVERAGE & Leverage: total debt divided by total assets \\
B_M & Book to market ratio \\
IND & Industry: dummy variable takes value of 1 if the firm belongs to either an envir \\
& or socially sensitive industry
\end{tabular}


Table 3. Correlation matrix

\begin{tabular}{|c|c|c|c|c|c|c|c|c|c|c|c|c|c|c|c|c|}
\hline & & 1 & 2 & 3 & 4 & 5 & 6 & 7 & 8 & 9 & 10 & 11 & 12 & 13 & 14 & 15 \\
\hline 1 & CSR & 1 & & & & & & & & & & & & & & \\
\hline 2 & COMMUNITY & $0.793 * * *$ & 1 & & & & & & & & & & & & & \\
\hline 3 & EMPLOYEE & $0.801 * * *$ & $0.410^{* * *}$ & 1 & & & & & & & & & & & & \\
\hline 4 & ENVIRONMENT & $0.808 * * *$ & $0.326^{* * *}$ & $0.703 * * *$ & 1 & & & & & & & & & & & \\
\hline 5 & EQUITY_INCENTIVE & $-0.061 * *$ & -0.033 & $-0.070 * * *$ & $-0.055^{* *}$ & 1 & & & & & & & & & & \\
\hline 6 & BONUS & $-0.078 * * *$ & $-0.073 * * *$ & $-0.073 * * *$ & $-0.044 *$ & $-0.197 * * *$ & 1 & & & & & & & & & \\
\hline 7 & FIRST_YEAR & 0.035 & 0.025 & $0.041^{*}$ & 0.024 & $-0.193 * * *$ & $0.098 * * *$ & 1 & & & & & & & & \\
\hline 8 & LAST_YEAR & 0.006 & -0.002 & 0.016 & 0.006 & 0.024 & -0.008 & $-0.059 * *$ & 1 & & & & & & & \\
\hline 9 & AGE & 0.019 & 0.006 & 0.012 & 0.028 & $0.146^{* * *}$ & $0.075 * * *$ & $-0.153 * * *$ & $0.184 * * *$ & 1 & & & & & & \\
\hline 10 & POWER_ENTR & 0.03 & -0.003 & 0.03 & $0.054 * *$ & $0.275^{* * *}$ & -0.011 & $-0.388 * * *$ & $0.068 * * *$ & $0.283^{* * *}$ & 1 & & & & & \\
\hline 11 & P_IND & $0.088 * * *$ & $0.069 * * *$ & $0.062 * *$ & $0.077 * * *$ & $-0.083 * * *$ & 0.004 & 0.012 & 0.019 & -0.033 & 0.002 & 1 & & & & \\
\hline 12 & SIZE & $0.329 * * *$ & $0.257 * * *$ & $0.287 * * *$ & $0.256^{* * *}$ & $0.043^{*}$ & $0.065^{* *}$ & 0.027 & 0.036 & $0.114 * * *$ & $0.071 * * *$ & $0.077 * * *$ & 1 & & & \\
\hline 13 & ROA & -0.007 & -0.024 & -0.021 & 0.026 & $0.172 * * *$ & -0.008 & -0.03 & -0.039 & -0.028 & -0.014 & 0.01 & $-0.359 * * *$ & 1 & & \\
\hline 14 & LEVERAGE & $0.091 * * *$ & $0.099 * * *$ & $0.103 * * *$ & 0.022 & $-0.164 * * *$ & $-0.056^{* *}$ & $0.047^{*}$ & 0.016 & 0.032 & $0.049^{*}$ & $0.056^{* *}$ & $0.405^{* * *}$ & $-0.339 * * *$ & 1 & \\
\hline 15 & B_M & $-0.071 * * *$ & -0.011 & $-0.071 * * *$ & $-0.103 * * *$ & $-0.245^{* * *}$ & $-0.068 * * *$ & 0.02 & 0.03 & $0.057^{* *}$ & 0.008 & -0.021 & $0.303 * * *$ & $-0.512 * * *$ & $0.096^{* * *}$ & 1 \\
\hline 16 & IND & $0.318 * * *$ & $0.186^{* * *}$ & $0.272 * * *$ & $0.325 * * *$ & $-0.122 * * *$ & $-0.046^{*}$ & -0.009 & -0.015 & 0.03 & 0.034 & 0.023 & $0.056^{* *}$ & 0.035 & 0.025 & -0.035 \\
\hline
\end{tabular}

${ }^{*} \mathrm{p}<0.05,{ }^{* *} \mathrm{p}<0.01,{ }^{* * *} \mathrm{p}<0.001$

\section{CSR}

COMMUNITY

EMPLOYEE

ENVIRONMENT

EQUITY INCENTIVE

\section{BONUS}

FIRST_YEAR

LAST_YEAR

AGE

POWER_ENTR

P_IND

SIZE

ROA

LEVERAGE
EIRIS overall CSR measure

EIRIS community-related CSR measure

EIRIS employee-related CSR measure

EIRIS environment-related CSR measure

Long-term incentives: dollar change in the value of CEO's stock and option holdings that would come from a one percentage point increase in the company stock price (following Bergstresser and Philippon, 2006)

Short-term incentives: log transformation of CEOs' annual bonus

Incoming CEO: dummy variable takes value of 1 if the CEO served in the company for the first year, zero otherwise

Departing CEO: dummy variable takes value of 1 in the last year of the CEO's tenure, zero otherwise

Career concerns: age of the CEO

Power and Entrenchment: factor analysis between the CEOs' tenure and the CEOs' duality

Board independence: dummy variable takes on the value of 1 (zero) if the proportion of independent non-executives on the board is more (less) than $33 \%$

Firm size: natural logarithm of total assets

Firm operating profitability: operating profit divided total assets

Leverage: total debt divided by total assets 
Table 4. CEO's Incentives and Corporate Social Responsibility(OLS estimation)

\begin{tabular}{|c|c|c|c|c|}
\hline & & & & \\
\hline & CSR & COMMUNITY & EMPLOYEE & ENVIRONMENT \\
\hline & (1) & $(2)$ & (3) & $(4)$ \\
\hline \multicolumn{5}{|l|}{ CEO Incentives } \\
\hline \multirow[t]{2}{*}{ EQUITY_INCENTIVE } & $-0.3775^{* * *}$ & $-0.1034^{*}$ & $-0.1031 * * *$ & $-0.1710 * * *$ \\
\hline & {$[-4.118]$} & {$[-1.917]$} & {$[-4.324]$} & {$[-4.373]$} \\
\hline \multirow[t]{2}{*}{ BONUS } & $-0.0260 * * *$ & $-0.0106^{* * *}$ & $-0.0060 * * *$ & $-0.0093 * * *$ \\
\hline & {$[-4.598]$} & {$[-3.046]$} & {$[-3.981]$} & {$[-3.586]$} \\
\hline \multirow[t]{2}{*}{ FIRST_YEAR } & $0.0924 * * *$ & 0.0244 & $0.0283 * * *$ & $0.0398 * * *$ \\
\hline & {$[2.595]$} & {$[1.170]$} & {$[2.646]$} & {$[2.596]$} \\
\hline \multirow[t]{2}{*}{ LAST_YEAR } & 0.0026 & -0.0071 & 0.0079 & 0.0018 \\
\hline & {$[0.068]$} & {$[-0.316]$} & {$[0.730]$} & {$[0.104]$} \\
\hline \multirow[t]{2}{*}{ AGE } & 0.0004 & 0.0000 & -0.0001 & 0.0005 \\
\hline & {$[0.116]$} & {$[0.008]$} & {$[-0.124]$} & {$[0.327]$} \\
\hline \multirow[t]{2}{*}{ POWER_ENTR } & $0.0370 * *$ & 0.0024 & $0.0109 * *$ & $0.0237 * * *$ \\
\hline & {$[2.039]$} & {$[0.225]$} & {$[2.174]$} & {$[2.996]$} \\
\hline \multicolumn{5}{|l|}{ Controls } \\
\hline \multirow[t]{2}{*}{ P_IND } & $0.1075^{*}$ & $0.0559^{*}$ & 0.0156 & 0.0359 \\
\hline & {$[1.835]$} & [1.712] & {$[0.907]$} & {$[1.371]$} \\
\hline \multirow[t]{2}{*}{ SIZE } & $0.2201 * * *$ & $0.0845^{* * *}$ & $0.0511^{* * *}$ & $0.0845^{* * *}$ \\
\hline & {$[12.013]$} & [8.453] & [9.969] & [9.705] \\
\hline \multirow[t]{2}{*}{ ROA } & 0.0852 & 0.0854 & -0.0078 & 0.0076 \\
\hline & {$[0.334]$} & {$[0.592]$} & {$[-0.107]$} & {$[0.063]$} \\
\hline \multirow[t]{2}{*}{ LEVERAGE } & $-0.3504 * * *$ & -0.0668 & $-0.0650^{* *}$ & $-0.2186^{* * *}$ \\
\hline & {$[-3.421]$} & {$[-1.105]$} & {$[-2.359]$} & {$[-4.450]$} \\
\hline \multirow[t]{2}{*}{ B_M } & $-0.4039 * * *$ & $-0.1166^{* * *}$ & $-0.1051 * * *$ & $-0.1823 * * *$ \\
\hline & {$[-7.764]$} & {$[-3.939]$} & {$[-7.689]$} & {$[-7.711]$} \\
\hline \multirow[t]{2}{*}{ IND } & $0.4353 * * *$ & $0.1362 * * *$ & $0.0983 * * *$ & $0.2008 * * *$ \\
\hline & {$[8.134]$} & {$[4.872]$} & {$[6.320]$} & [7.324] \\
\hline \multirow[t]{2}{*}{ Constant } & $-0.6518^{* * *}$ & $-0.2396^{*}$ & -0.0719 & $-0.3404 * * *$ \\
\hline & {$[-2.819]$} & {$[-1.839]$} & {$[-1.165]$} & {$[-3.109]$} \\
\hline YEAR DUMMIES & YES & YES & YES & YES \\
\hline Observations & 2520 & 2,520 & 2,520 & 2,520 \\
\hline R-squared & 0.278 & 0.133 & 0.217 & 0.237 \\
\hline
\end{tabular}

Firm-cluster t-statistics in brackets

$* * * \mathrm{p}<0.01, * * \mathrm{p}<0.05, * \mathrm{p}<0.1$

CSR

COMMUNITY

EMPLOYEE

ENVIRONMENT
EIRIS overall CSR measure EIRIS community-related CSR measure EIRIS employee-related CSR measure EIRIS environment-related CSR measure 
EQUITY_INCENTIVE

BONUS

FIRST_YEAR

LAST_YEAR

AGE

POWER_ENTR

P_IND

SIZE

ROA

LEVERAGE

B_M

IND
Long-term incentives: dollar change in the value of CEO's stock and option holdings that would come from a one percentage point increase in the company stock price (following Bergstresser and Philippon, 2006)

Short-term incentives: log transformation of CEOs' annual bonus

Incoming CEO: dummy variable takes value of 1 if the CEO served in the company for the first year, zero otherwise

Departing CEO: dummy variable takes value of 1 in the last year of the CEO's tenure, zero otherwise

Career concerns: age of the CEO

Power and Entrenchment: factor analysis between the CEOs' tenure and the CEOs' duality Board independence: dummy variable takes on the value of 1 (zero) if the proportion of independent non-executives on the board is more (less) than $33 \%$

Firm size: natural logarithm of total assets

Firm operating profitability: operating profit divided total assets

Leverage: total debt divided by total assets

Book to market ratio

Industry: dummy variable takes value of 1 if the firm belongs to either an environmentally or socially sensitive industry 
Table 5. Regressions model controlling for endogeneity between monetary incentives and CSR

\begin{tabular}{|c|c|c|c|c|c|c|}
\hline \multirow[b]{2}{*}{ VARIABLES } & \multicolumn{3}{|c|}{$\begin{array}{c}\text { Two-stage least squares with instrumental } \\
\text { variables }\end{array}$} & \multicolumn{3}{|c|}{$\begin{array}{c}\text { Three-stage least squares with simultaneous } \\
\text { equations }\end{array}$} \\
\hline & CSR & BONUS & EQUITY_INCENTIVE & CSR & BONUS & EQUITY_INCENTIVE \\
\hline EQUITY_INCENTIVE & $-1.2108 * * *$ & & & $-1.1109 * * *$ & & \\
\hline BONUS & $\begin{array}{l}{[-3.145]} \\
-0.2563 * * * \\
\Gamma-3.3941\end{array}$ & & & $\begin{array}{l}{[-4.672]} \\
-0.2520 * * * \\
{[-5369]}\end{array}$ & & \\
\hline FIRST_YEAR & $\begin{array}{l}0.1749 * * \\
{[2.374]}\end{array}$ & $\begin{array}{l}0.8847 * * * \\
{[4.621]}\end{array}$ & $\begin{array}{l}-0.0726 * * * \\
{[-5.862]}\end{array}$ & $0.2308^{* * *}$ & $\begin{array}{l}0.8726^{* * *} \\
{[4.906]}\end{array}$ & $\begin{array}{l}-0.0726^{* * *} \\
{[-5.385]}\end{array}$ \\
\hline LAST_YEAR & $\begin{array}{l}-0.0005 \\
{[-0.009]}\end{array}$ & $\begin{array}{l}0.1084 \\
{[0.578]}\end{array}$ & $\begin{array}{l}-0.0176 \\
{[-1.278]}\end{array}$ & $\begin{array}{l}0.0014 \\
{[0.024]}\end{array}$ & $\begin{array}{l}0.0784 \\
{[0.425]}\end{array}$ & $\begin{array}{l}-0.0176 \\
{[-1.258]}\end{array}$ \\
\hline AGE & $\begin{array}{l}0.0114 * * \\
{[2.136]}\end{array}$ & $\begin{array}{l}0.0219 \\
{[1.503]}\end{array}$ & $\begin{array}{l}0.0038 * * * \\
{[2.781]}\end{array}$ & $\begin{array}{l}0.0104 * * * \\
{[3.079]}\end{array}$ & $\begin{array}{l}0.0298 * * * \\
{[3.456]}\end{array}$ & $\begin{array}{l}0.0038 * * * \\
{[5.758]}\end{array}$ \\
\hline $\begin{array}{l}\text { POWER_ENTR } \\
\text { Controls }\end{array}$ & $\begin{array}{l}0.0544 * * \\
{[1.962]}\end{array}$ & $\begin{array}{l}-0.0528 \\
{[-0.740]}\end{array}$ & $\begin{array}{l}0.0514^{* * * *} \\
{[8.131]}\end{array}$ & $\begin{array}{l}0.0623 * * * \\
{[2.920]}\end{array}$ & $\begin{array}{l}-0.0549 \\
{[-0.940]}\end{array}$ & $\begin{array}{l}0.0514 * * * \\
{[11.573]}\end{array}$ \\
\hline P_IND & $\begin{array}{l}-0.0996 \\
{[-0.967]}\end{array}$ & $\begin{array}{l}-0.5237^{*} \\
{[-1.889]}\end{array}$ & $\begin{array}{l}-0.0793 * * * \\
{[-3.188]}\end{array}$ & $\begin{array}{l}-0.0928 \\
{[-1.338]}\end{array}$ & $\begin{array}{l}-0.5680 * * * \\
{[-3.215]}\end{array}$ & $\begin{array}{l}-0.0793 * * * \\
{[-5.923]}\end{array}$ \\
\hline SIZE & $\begin{array}{l}0.3118^{* * * *} \\
{[8.087]}\end{array}$ & $\begin{array}{l}0.2223 * * * \\
{[2.831]}\end{array}$ & $\begin{array}{l}0.0368 * * * \\
{[5.675]}\end{array}$ & $\begin{array}{l}0.3091 * * * \\
{[12.897]}\end{array}$ & $\begin{array}{l}0.2340 * * * \\
{[5.035]}\end{array}$ & $\begin{array}{l}0.0368 * * * \\
{[10.449]}\end{array}$ \\
\hline ROA & $\begin{array}{l}-0.0603 \\
{[-0.170]}\end{array}$ & $\begin{array}{l}-1.4835 \\
{[-1.377]}\end{array}$ & $\begin{array}{l}0.1693^{*} \\
{[1.737]}\end{array}$ & $\begin{array}{l}-0.1256 \\
{[-0.503]}\end{array}$ & $\begin{array}{l}-1.7453^{* *} \\
{[-2.190]}\end{array}$ & $\begin{array}{l}0.1693 * * * \\
{[2.801]}\end{array}$ \\
\hline LEVERAGE & $\begin{array}{l}-0.7875 * * * \\
{[-4.178]}\end{array}$ & $\begin{array}{l}-1.2901 * * * \\
{[-3.574]}\end{array}$ & $\begin{array}{l}-0.2163 * * * \\
{[-6.018]}\end{array}$ & $\begin{array}{l}-0.7974 * * * \\
{[-5.980]}\end{array}$ & $\begin{array}{l}-1.1323 * * * \\
{[-3.968]}\end{array}$ & $\begin{array}{l}-0.2163 * * * \\
{[-10.002]}\end{array}$ \\
\hline B_M & $\begin{array}{l}-0.5629 * * * \\
{[-5.823]}\end{array}$ & $\begin{array}{l}-0.1806 \\
{[-0.815]}\end{array}$ & $\begin{array}{l}-0.1593 * * * \\
{[-9.502]}\end{array}$ & $\begin{array}{l}-0.5621 * * * \\
{[-8.574]}\end{array}$ & $\begin{array}{l}-0.2081 \\
{[-1.272]}\end{array}$ & $\begin{array}{l}-0.1593 * * * \\
{[-12.830]}\end{array}$ \\
\hline IND & $\begin{array}{l}0.2434 * * * \\
{[2.646]}\end{array}$ & $\begin{array}{l}-0.4099 * * \\
{[-2.266]}\end{array}$ & $\begin{array}{l}-0.0800 * * * \\
{[-4.510]}\end{array}$ & $\begin{array}{l}0.2559 * * * \\
{[4.476]}\end{array}$ & $\begin{array}{l}-0.3271 * * \\
{[-2.390]}\end{array}$ & $\begin{array}{l}-0.0800 * * * \\
{[-7.680]}\end{array}$ \\
\hline BASE SALARY & & $\begin{array}{l}1.1500^{* * *} \\
{[7.370]}\end{array}$ & $\begin{array}{l}-0.3361 * * * \\
{[-13.393]}\end{array}$ & & $\begin{array}{l}1.0622 * * * \\
{[4.909]}\end{array}$ & $\begin{array}{l}-0.3361 * * * \\
{[-20.426]}\end{array}$ \\
\hline EQUITY_IV & & $\begin{array}{l}1.5357 \\
{[1.298]}\end{array}$ & $\begin{array}{l}0.2205^{*} \\
{[1.955]}\end{array}$ & & $\begin{array}{l}1.9132 * * * \\
{[2.865]}\end{array}$ & $\begin{array}{l}0.2205^{* * *} \\
{[3.417]}\end{array}$ \\
\hline BONUS_IV & & $\begin{array}{l}0.4267 * * * \\
{[3.579]}\end{array}$ & $\begin{array}{l}-0.0013 \\
{[-0.138]}\end{array}$ & & $\begin{array}{l}0.3827 * * * \\
{[5.938]}\end{array}$ & $\begin{array}{l}-0.0013 \\
{[-0.241]}\end{array}$ \\
\hline Constant & $\begin{array}{l}-1.0090 * * * \\
{[-2.954]}\end{array}$ & $\begin{array}{l}-3.9071 * * * \\
{[-3.506]}\end{array}$ & $\begin{array}{l}0.6524 * * * \\
{[5.164]}\end{array}$ & & & \\
\hline YEAR DUMMIES & YES & YES & YES & YES & YES & YES \\
\hline Observations & 2520 & 2520 & 2520 & 2520 & 2520 & 2520 \\
\hline
\end{tabular}

Firm-cluster t-statistics in brackets

$* * * \mathrm{p}<0.01,{ }^{* *} \mathrm{p}<0.05,{ }^{*} \mathrm{p}<0.1$ 


CSR
EQUITY_INCENTIVE
BONUS
FIRST_YEAR
LAST_YEAR
AGE
POWER_ENTR
P_IND
SIZE
ROA
LEVERAGE
B_M
IND
BASE SALARY
EQUITY_IV
BONUS_IV

EIRIS overall CSR measure

Long-term incentives: dollar change in the value of CEO's stock and option holdings that would come from a one percentage point increase in the company stock price (following Bergstresser and Philippon, 2006)

Short-term incentives: log transformation of CEOs' annual bonus Incoming CEO: dummy variable takes value of 1 if the CEO served in the company for the first year, zero otherwise

Departing CEO: dummy variable takes value of 1 in the last year of the CEO's tenure, zero otherwise

Career concerns: age of the CEO

Power and Entrenchment: factor analysis between the CEOs' tenure and the CEOs' duality Board independence: dummy variable takes on the value of 1 (zero) if the proportion of independent non-executives on the board is more (less) than $33 \%$

Firm size: natural logarithm of total assets

Firm operating profitability: operating profit divided total assets

Leverage: total debt divided by total assets

Book to market ratio

Industry: dummy variable takes value of 1 if the firm belongs to either an environmentally or socially sensitive industry

Logarithm of CEO's base salary

Yearly mean of equity incentives provided to the CEOs of all firms belonging to the 2digits SIC code of firm $i$, excluding the equity incentives provided to the CEO of firm $i$ Yearly mean of bonus provided to the CEOs of all firms belonging to the 2-digits SIC code of firm $i$, excluding the bonus provided to the CEO of firm $i$ 


\section{Appendix A}

Estimates of a stock option's sensitivity to stock price are calculated based on the Black-Scholes (1973) formula for valuing European call options, as modified to account for dividend payout by Merton (1973).

$$
\text { Option value }=\left[\mathrm{S} e^{-d T} \mathrm{~N}(\mathrm{Z})-\mathrm{X} e-r T \mathrm{~N}\left(\mathrm{Z}-\sigma \mathrm{T}^{(1 / 2}\right)\right]
$$

Where

$\mathrm{Z}=\left[\ln (\mathrm{S} / \mathrm{X})+\mathrm{T}\left(\mathrm{r}-\mathrm{d}+\sigma^{2} / 2\right] / \sigma \mathrm{T}^{(1 / 2)}\right.$

$\mathrm{N}=$ cumulative probability function for the normal distribution

$\mathrm{S}=$ price of the underlying stock

$\mathrm{X}=$ exercise price of the option

$\sigma=$ expected stock-return volatility over the life of the option

$\mathrm{r}=$ risk-free interest rate

$\mathrm{d}=$ expected dividend yield over the life of the option

The sensitivity with respect to a $1 \%$ change in stock price is defined as:

$[\delta($ optionvalue $) / \delta($ price $)] *($ price $/ 100)=e^{-d T} * N(Z) *($ price $/ 100)$ 